\title{
Fragmentation of Protonated Ions of Peptides Containing Cysteine, Cysteine Sulfinic Acid, and Cysteine Sulfonic Acid
}

\author{
Yinsheng Wang, Shetty Vivekananda, Lijie Men, and Qibin Zhang \\ Department of Chemistry, University of California at Riveirside, Riverside, California, USA
}

\begin{abstract}
The oxidation of the sulfhydryl group in cysteine to sulfenic acid, sulfinic acid, and sulfonic acid in proteins is important in a number of enzymatic processes. In this study we examined the fragmentation of four peptides containing cysteine, cysteine sulfinic acid $\left(\mathrm{Cys}_{-} \mathrm{SO}_{2} \mathrm{H}\right)$, and cysteine sulfonic acid $\left(\mathrm{Cys}-\mathrm{SO}_{3} \mathrm{H}\right)$ in an ion-trap mass spectrometer. Our results show that the presence of a Cys- $\mathrm{SO}_{2} \mathrm{H}$ in a peptide leads to preferential cleavage of the amide bond at the C-terminal side of the oxidized cysteine residue. The results are important for the determination of the site of the cysteine oxidation and might be useful for the sequencing of cysteine-containing peptides. (J Am Soc Mass Spectrom 2004, 15, 697-702) () 2004 American Society for Mass Spectrometry
\end{abstract}

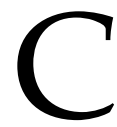
ysteine sulfenic acid (Cys-SOH) is not uncommon [1]; it exists in native proteins, and it can also be introduced via mild oxidation $[2,3]$. In the latter, active-site cysteine residues of some enzymes can be selectively oxidized at neutral $\mathrm{pH}$ [4-6]. The selective oxidation is due to low $\mathrm{pKa}$ for those cysteine residues in the local protein environment, which leads to the formation of cysteine thiolate anion $\left(\mathrm{Cys}_{-} \mathrm{S}^{-}\right)$. The thiolate anion can readily be oxidized by $\mathrm{H}_{2} \mathrm{O}_{2}$ to give Cys-SOH [4, 7]. The Cys-SOH is unstable and it reacts with any accessible thiol to form a disulfide or undergoes further oxidation to give cysteine sulfinic acid $\left(\mathrm{Cys}-\mathrm{SO}_{2} \mathrm{H}\right)$ and cysteine sulfonic acid $\left(\mathrm{Cys}-\mathrm{SO}_{3} \mathrm{H}\right)$ [2]. The formation of $\mathrm{Cys}-\mathrm{SO}_{2} \mathrm{H}$ and $\mathrm{Cys}-\mathrm{SO}_{3} \mathrm{H}$ has been implicated in the activation of matrix metalloproteinase-7 (MMP-7) [8] and nitrile hydratase [9]. The oxidation to $\mathrm{Cys}-\mathrm{SO}_{2} \mathrm{H}$ and $\mathrm{Cys}-\mathrm{SO}_{3} \mathrm{H}$ is generally thought to be irreversible [2]. However, recent studies show that the oxidation of cysteine to $\mathrm{Cys}-\mathrm{SO}_{2} \mathrm{H}$ in human peroxiredoxin is reversible in vivo [6] and a yeast enzyme that catalyzes this reaction has been identified [10]. In addition, the oxidation of a cysteine residue can yield intramolecular sulfenamide, sulfinamide, and sulfonamide while the cysteine residue is in close proximity to the N-terminus or a lysine residue $[11,12]$.

Mass spectrometry has been widely used in the structure elucidation of biomolecules including peptides [13-15]. The effect of an acidic amino acid, i.e., aspartic acid, glutamic acid, and $\mathrm{Cys}_{-} \mathrm{SO}_{3} \mathrm{H}$, on the fragmentation of protonated peptide ions has been well

Published online March 1, 2004

Address reprint requests to Dr. Y. Wang, Department of Chemistry-027, University of California at Riverside, Riverside, CA 92521-0403, USA. E-mail: yinsheng.wang@ucr.edu studied [16-22]. A general conclusion emerging from these studies appears to support that selective cleavage at the C-terminal side of the acidic amino acid residue can occur when the number of ionizing protons does not exceed the number of arginines [16, 20-22]. This is largely attributed to the intramolecular ionic interaction between the side chain of acidic amino acids and the guanidino group of arginine. Non-selective cleavages, however, can occur while the number of ionizing protons exceeds the number of arginine residues in a peptide [16, 20-22]. No systematic study, however, has been reported for the fragmentation of peptides containing a Cys- $\mathrm{SO}_{2} \mathrm{H}$. In this paper we report the fragmentation of protonated ions of peptides containing a cysteine, Cys- $\mathrm{SO}_{2} \mathrm{H}$, or Cys- $\mathrm{SO}_{3} \mathrm{H}$.

\section{Experimental}

Peptides used in this study were either purchased from Sigma (St. Louis, MO) or synthesized on an ABI 433 B peptide synthesizer (Applied Biosystems, Foster City, CA) by using standard solid-phase chemistry [23]. Peptides containing an oxidized cysteine residue were prepared by oxidation using Fenton reagents $\left(\mathrm{Fe}^{2+} /\right.$ $\mathrm{H}_{2} \mathrm{O}_{2}$ ) and subjected directly to MS/MS analysis or purified by reversed-phase high performance liquid chromatography (HPLC) prior to MS analysis. Under a typical reaction condition, $100-\mu \mathrm{M}$ peptide solution was incubated at $37{ }^{\circ} \mathrm{C}$ in the presence of $0.25 \mathrm{mM} \mathrm{FeSO}_{4}$ and $0.25 \mathrm{mM} \mathrm{H}_{2} \mathrm{O}_{2}$ for $10-30 \mathrm{~min}$. The reaction was terminated by adding aliquots of methionine solution until its concentration reached $1 \mathrm{mM}$. For all the sequences studied, we were able to obtain peptides with the cysteine residue being oxidized to $\mathrm{Cys}-\mathrm{SO}_{2} \mathrm{H}$ and Cys- $\mathrm{SO}_{3} \mathrm{H}$. The combined yield for the formation of 


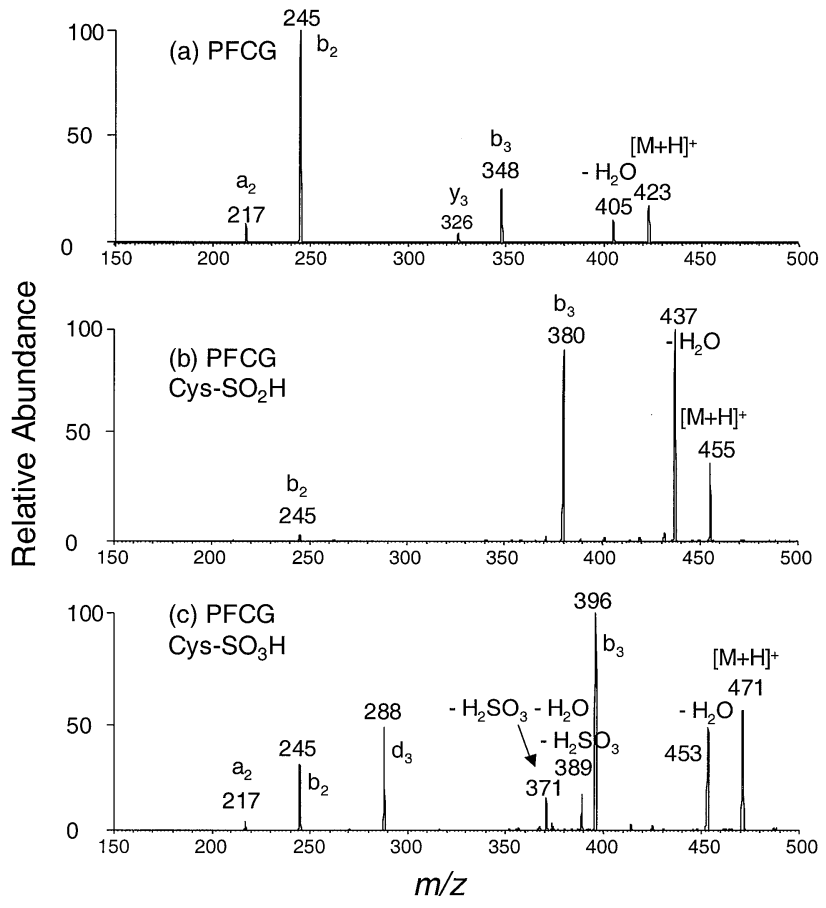

Figure 1. Product-ion spectra of electrospray-produced $[\mathrm{M}+$ $\mathrm{H}^{+}$ions of PFCG (a), $\operatorname{PFC}\left(\mathrm{SO}_{2} \mathrm{H}\right) \mathrm{G}(\mathbf{b})$, and $\operatorname{PFC}\left(\mathrm{SO}_{3} \mathrm{H}\right) \mathrm{G}(\mathbf{c})$.

these two oxidation products varied with the sequences of peptides and was estimated to be approximately $20-50 \%$ based on peak areas in HPLC trace. It should be noted that the oxidation condition was not rigorously optimized. The amounts of the two oxidation products formed were similar, but could differ by up to 5 -fold depending on the sequence of peptide and the oxidation time.

ESI-MS experiments were carried out on an LCQ Deca XP ion-trap mass spectrometer (ThermoFinnigan, San Jose, CA). An equal-volume solvent mixture of acetonitrile and water was used as the carrier and electrospray solvent; a $1-\mu \mathrm{L}$ aliquot of $10-\mu \mathrm{M}$ sample solution was injected in each run. The spray voltage was $4.5 \mathrm{kV}$, and the temperature for the heated capillary was $200{ }^{\circ} \mathrm{C}$. The automated gain control (AGC) feature was employed in MS and MS/MS, and the maximum numbers of ions for these modes were set to be $5 \times 10^{7}$ and $2 \times 10^{7}$, respectively. The mass width for precursor ion selection in MS/MS was $2 \mathrm{~m} / \mathrm{z}$, and the normalized collisional energy was optimized $(18-25 \%)$ so that the precursor ion is clearly present but not the most abundant in the product-ion spectrum. Each spectrum was obtained by averaging approximately 50 scans, and the time for each scan was $0.1 \mathrm{~s}$.

\section{Results and Discussion}

\section{PFCG, PFC $\left(\mathrm{SO}_{2} \mathrm{H}\right) \mathrm{G}$ and PFC $\left(\mathrm{SO}_{3} \mathrm{H}\right) \mathrm{G}$}

The product-ion spectrum of the ESI-produced [M + $\mathrm{H}]^{+}$ion of PFCG shows an abundant $\mathrm{b}_{2}$ ion of $\mathrm{m} / z 245$

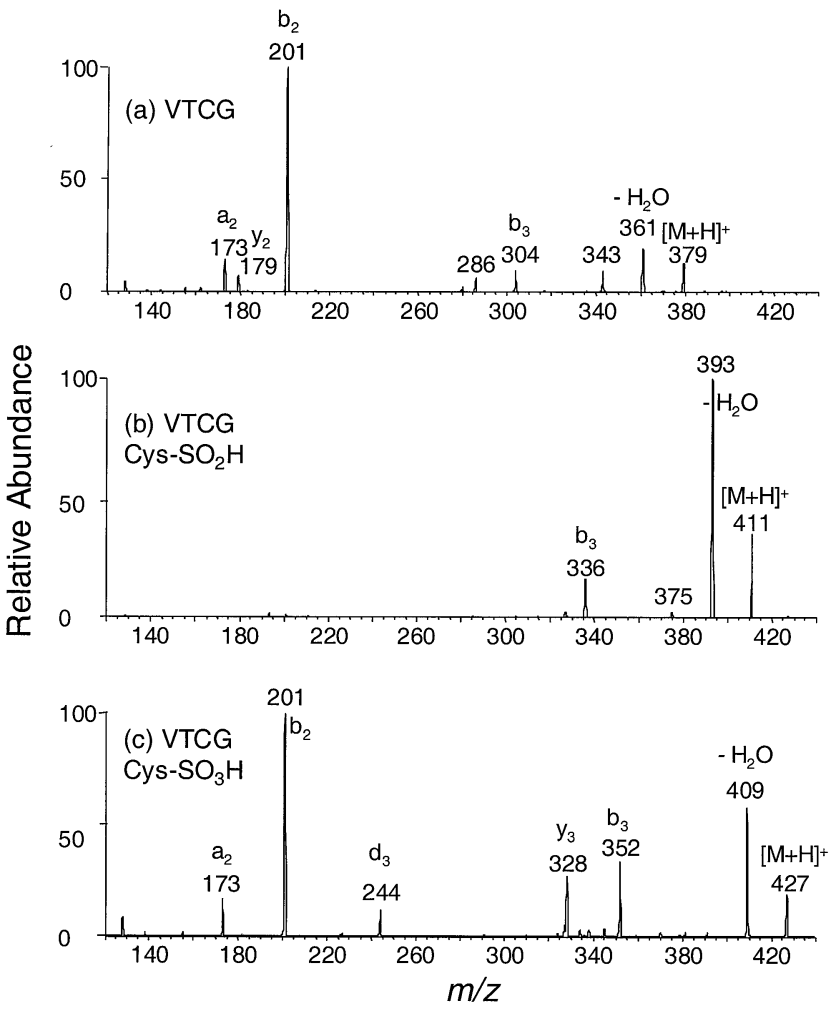

Figure 2. Product-ion spectra of electrospray-produced $[\mathrm{M}+$ $\mathrm{H}^{+}$ions of VTCG (a), VTC $\left(\mathrm{SO}_{2} \mathrm{H}\right) \mathrm{G}(\mathbf{b})$, and VTC $\left(\mathrm{SO}_{3} \mathrm{H}\right) \mathrm{G}(\mathbf{c})$.

(Figure 1a). While the cysteine (Cys) is oxidized to Cys $-\mathrm{SO}_{2} \mathrm{H}$, the product-ion spectrum gives a much less abundant $\mathrm{b}_{2}$ ion. Water loss and cleavage at the $\mathrm{C}$ terminal side of the $\mathrm{Cys}-\mathrm{SO}_{2} \mathrm{H}$, however, become very facile, which give an ion of $\mathrm{m} / \mathrm{z} 437$ and $\mathrm{a}_{3}$ ion, respectively (Figure $1 \mathrm{~b}$ ). Similarly, the product-ion spectrum of the ESI-produced $[\mathrm{M}+\mathrm{H}]^{+}$ion of $\mathrm{PFC}\left(\mathrm{SO}_{3} \mathrm{H}\right) \mathrm{G}$ shows that the formation of $[\mathrm{M}+\mathrm{H}-$ $\left.\mathrm{H}_{2} \mathrm{O}\right]^{+}$and $\mathrm{b}_{3}$ ions occurs readily. The $\mathrm{b}_{2}$ ion, however, is still produced abundantly (Figure 1c).

\section{$\operatorname{VTCG}, \operatorname{VTC}\left(\mathrm{SO}_{2} \mathrm{H}\right) \mathrm{G}$, and $\operatorname{VTC}\left(\mathrm{SO}_{3} \mathrm{H}\right) \mathrm{G}$}

Similar to PFCG, the product-ion spectrum of the [M + $\mathrm{H}]^{+}$ion of VTCG shows the formation of an abundant $\mathrm{b}_{2}$ ion (Figure 2a). The oxidation of the Cys residue to Cys $-\mathrm{SO}_{2} \mathrm{H}$ and $\mathrm{Cys}-\mathrm{SO}_{3} \mathrm{H}$ again leads to the facile formation of $a b_{3}$ ion (Figure $2 b$ and $c$ ). It is worth noting that the enhancement for the formation of the $b_{3}$ ion is relatively more for $\operatorname{VTC}\left(\mathrm{SO}_{2} \mathrm{H}\right) \mathrm{G}$ than for VTC $\left(\mathrm{SO}_{3} \mathrm{H}\right) \mathrm{G}$ because the $\mathrm{b}_{3}$ ion is the only fragment ion other than the water loss fragment observed in the product-ion spectrum for the former, whereas the $b_{3}$ ion is produced with similar abundance as other fragment ions, i.e., $a_{2}, b_{2}$, and $y_{3}$, in that of the latter (Figure $2 b$ and $c$ ). This conclusion seems to be also valid for the PFCG with the Cys being oxidized to $\mathrm{Cys}-\mathrm{SO}_{2} \mathrm{H}$ and Cys- $\mathrm{SO}_{3} \mathrm{H}$ (vide supra). 


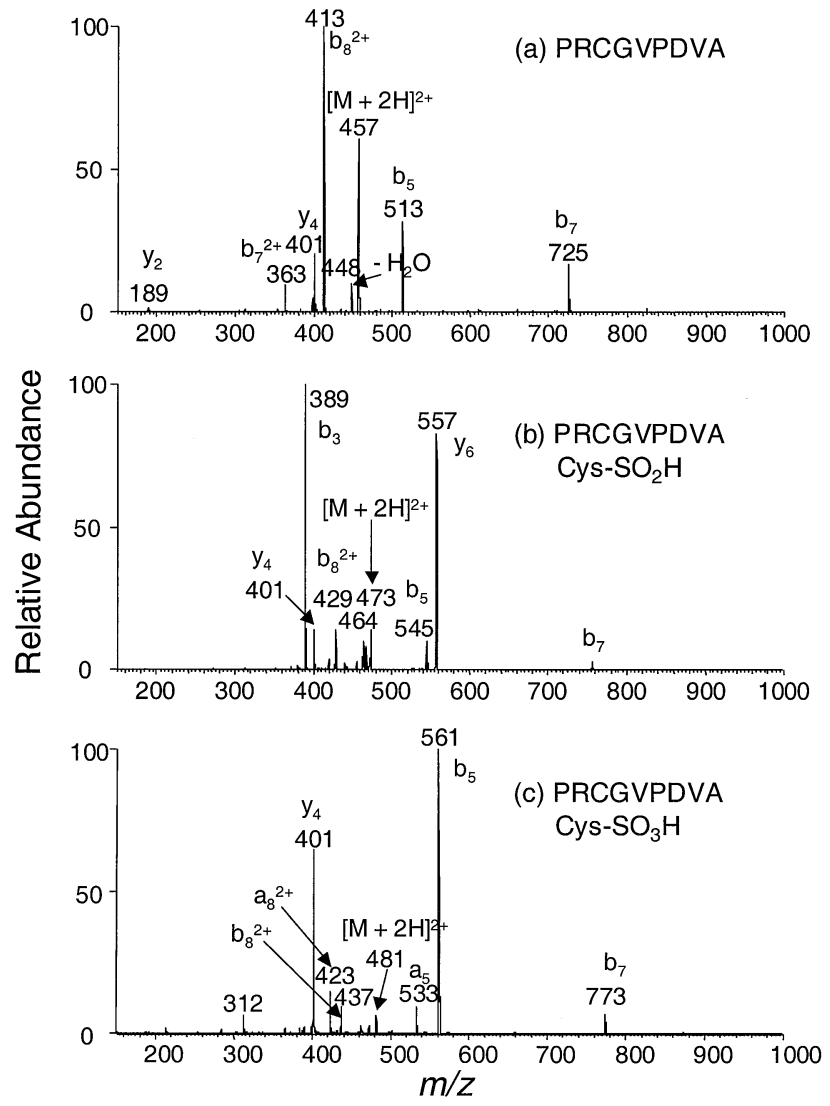

Figure 3. Product-ion spectra of electrospray-produced $[\mathrm{M}+$ $2 \mathrm{H}]^{2+}$ ions of PRCGVPDVA (a), PRC $\left(\mathrm{SO}_{2} \mathrm{H}\right)$ GVPDVA (b), and $\operatorname{PRC}\left(\mathrm{SO}_{3} \mathrm{H}\right)$ GVPDVA (c).

\section{PRCGVPDVA, PRC $\left(\mathrm{SO}_{2} \mathrm{H}\right)$ GVPDVA, and $\mathrm{PRC}\left(\mathrm{SO}_{3} \mathrm{H}\right) \mathrm{GVPDVA}$}

The above results were obtained with short peptides where singly-charged precursor ions were used for collisional activation. It is important to demonstrate whether the characteristic cleavages at the C-terminal side of the $\mathrm{Cys}-\mathrm{SO}_{2} \mathrm{H}$ and $\mathrm{Cys}-\mathrm{SO}_{3} \mathrm{H}$ also occur in longer peptides. To this end, we oxidized PRCGVPDVA and RGDGGGCR by Fenton reagents $\left(\mathrm{Fe}^{2+} /\right.$ $\mathrm{H}_{2} \mathrm{O}_{2}$ ) and separated the mixture by reverse-phase HPLC. The former peptide is part of the cysteine switch domain of matrix metalloproteinase-7 (MMP-7), and it has been shown that $\mathrm{HOCl}$ can oxidize the cysteine residue in this peptide to $\mathrm{Cys}-\mathrm{SO}_{2} \mathrm{H}$ and $\mathrm{Cys}-\mathrm{SO}_{3} \mathrm{H}$ [8]. Similarly, we found that the Fenton reagents can oxidize the cysteine residue to yield $\mathrm{Cys}-\mathrm{SO}_{2} \mathrm{H}$ and Cys$\mathrm{SO}_{3} \mathrm{H}$.

The product-ion spectrum of the ESI-produced [M + $2 \mathrm{H}]^{2+}$ ion of the unmodified peptide shows the formation of $y_{2}, y_{4}$, and their complementary $b_{7}$ and $b_{5}$ ions (Figure $3 a$ ). In addition, we observed an abundant $b_{8}^{2+}$ ion. The product-ion spectrum changes quite obviously while a Cys $-\mathrm{SO}_{2} \mathrm{H}$ residue replaces the $\mathrm{Cys}$ residue. The most distinctive alteration is the production of an abundant $b_{3}$ and its complementary $\mathrm{y}_{6}$ ions (Figure $3 b$ ).

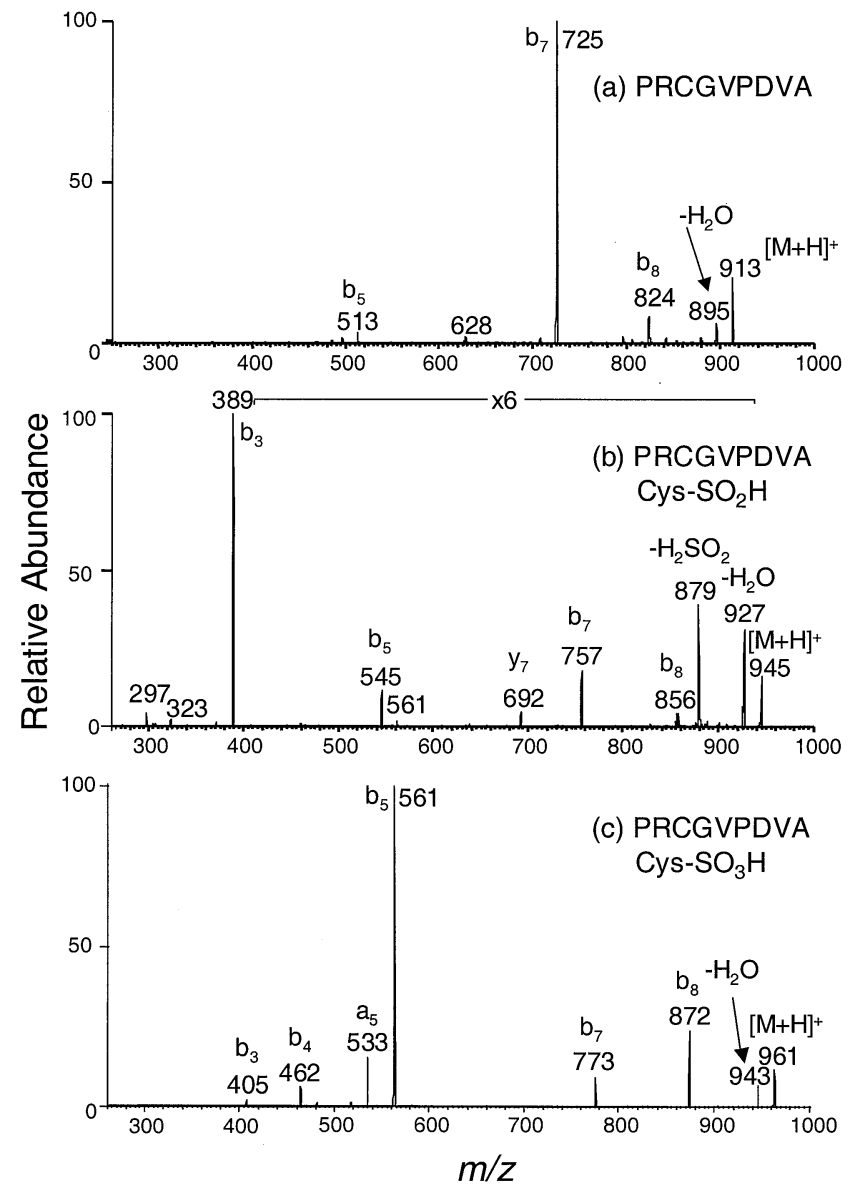

Figure 4. Product-ion spectra of electrospray-produced $[\mathrm{M}+$ $\mathrm{H}^{+}$ions of PRCGVPDVA (a), PRC $\left(\mathrm{SO}_{2} \mathrm{H}\right)$ GVPDVA (b), and PRC $\left(\mathrm{SO}_{3} \mathrm{H}\right)$ GVPDVA (c).

Again the formation of these two ions requires cleavage at the C-terminal side of the $\mathrm{Cys}-\mathrm{SO}_{2} \mathrm{H}$ residue. The $\mathrm{b}_{3}$ and $\mathrm{y}_{6}$ ions, however, are almost undetectable in the $\mathrm{MS} / \mathrm{MS}$ of the $[\mathrm{M}+2 \mathrm{H}]^{2+}$ ion of the peptide containing a Cys-SO ${ }_{3} \mathrm{H}$ (Figure 3c). Comparing to the product-ion spectrum of the $[\mathrm{M}+2 \mathrm{H}]^{2+}$ ion of the unmodified peptide, that of the peptide containing the $\mathrm{Cys}_{2} \mathrm{SO}_{3} \mathrm{H}$ residue gives more abundant $b_{5}$ and $y_{4}$ ions. It is worth noting the $b_{5}$ and $y_{4}$ ions were not produced abundantly in the product-ion spectrum of the $[\mathrm{M}+2 \mathrm{H}]^{2+}$ ion of the peptide bearing a Cys- $\mathrm{SO}_{2} \mathrm{H}$. We attribute this to the presence of an energetically more favorable cleavage pathway, i.e., the production of $b_{3}$ and $y_{6}$ ions, in the fragmentation of the $[\mathrm{M}+2 \mathrm{H}]^{2+}$ ion of the latter peptide.

For comparison, we also acquired the product-ion spectra of the $[\mathrm{M}+\mathrm{H}]^{+}$ions of PRCGVPDVA, PRC $\left(\mathrm{SO}_{2} \mathrm{H}\right)$ GVPDVA, and PRC $\left(\mathrm{SO}_{3} \mathrm{H}\right)$ GVPDVA (Figure 4). In contrast to the product-ion spectra of the doubly-charged precursors, we did not observe abundant $y$ ions in those of the singly-charged precursors (Figures 3 and 4). This is likely due to the fact that the arginine residue, which is the most favorable site for protonation in this peptide, is in close proximity to the 


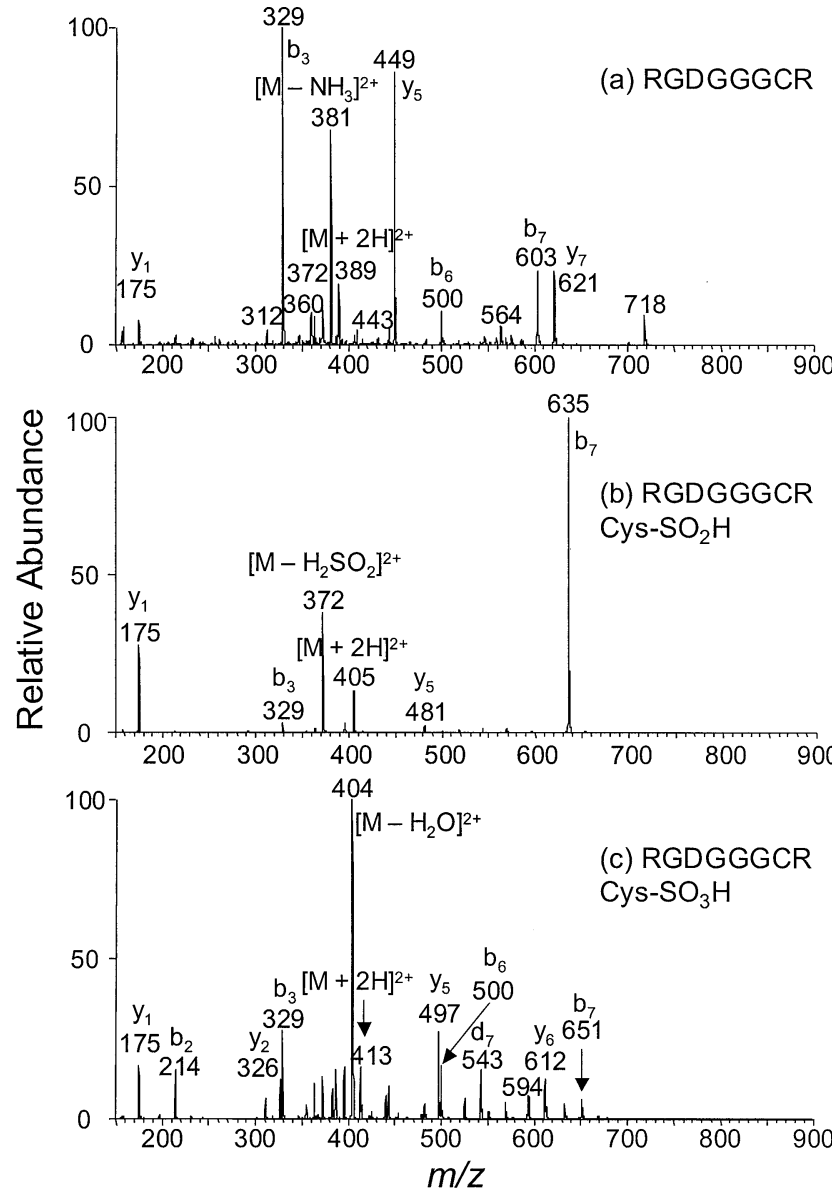

Figure 5. Product-ion spectra of electrospray-produced $[\mathrm{M}+$ $2 \mathrm{H}]^{2+}$ ions of RGDGGGCR (a), RGDGGGC $\left(\mathrm{SO}_{2} \mathrm{H}\right) \mathrm{R}(\mathbf{b})$, and RGDGGGC $\left(\mathrm{SO}_{3} \mathrm{H}\right) \mathrm{R}(\mathbf{c})$.

$\mathrm{N}$-terminus; fragments bearing the C-terminus of the peptide, therefore, are unlikely to be protonated. Moreover, the presence of a Cys-SO $\mathrm{S}_{2} \mathrm{H}$ again results in facile cleavage of the amide bond at the C-terminal side of Cys- $\mathrm{SO}_{2} \mathrm{H}$ to give a dominant $\mathrm{b}_{3}$ ion (Figure $4 \mathrm{~b}$ ). In contrast, the product-ion spectrum of the $[\mathrm{M}+\mathrm{H}]^{+}$ion of PRC $\left(\mathrm{SO}_{3} \mathrm{H}\right) \mathrm{GVPDVA}$ shows that the most abundant cleavage occurs at $\mathrm{N}$-terminal side of proline to give a $b_{5}$ ion. The $b_{3}$ ion $(m / z 405)$ is also produced, but in very low abundance (Figure 4c).

Tsaprailis et al. [21] reported that collisional activation of protonated peptide ions containing arginine and aspartic acid or glutamic acid residues results in selective cleavages at the C-terminal side of the acidic residues if the number of ionizing protons does not exceed the number of arginine residues. Our data with the $[\mathrm{M}+\mathrm{H}]^{+}$ion of the PRCGVPDVA appear not to be consistent with this view because the selective cleavage occurs at the amide bond between valine and proline, which gives the $b_{5}$ ion. However, it has been recently shown that cleavage $\mathrm{N}$-terminal to a proline residue is a very facile process especially when the residue at the $\mathrm{N}$-terminal side of the proline is a valine [24, 25]. It seems that sequence context plays a more important
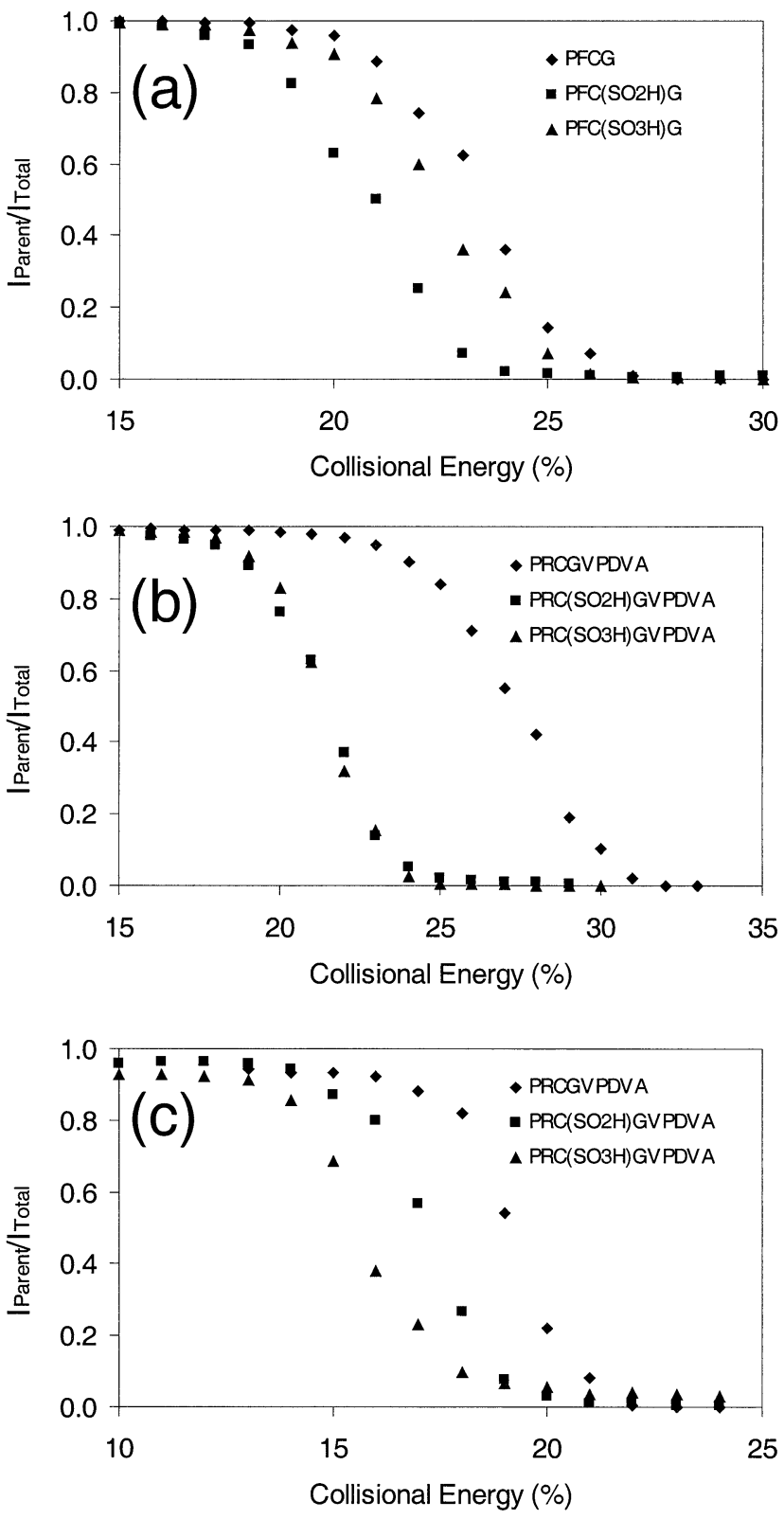

Figure 6. A plot of the fraction of parent ion intensity $\left(\mathrm{I}_{\text {parent }} /\right.$ $\left.\mathrm{I}_{\text {total }}\right)$ versus the collisional energy for the fragmentation of the $[\mathrm{M}$ $+\mathrm{H}]^{+}$ions of PFCG, PFC $\left(\mathrm{SO}_{2} \mathrm{H}\right) \mathrm{G}$, and PFC $\left(\mathrm{SO}_{3} \mathrm{H}\right) \mathrm{G}(\mathbf{a})$. Similar plots for the fragmentation of the $[\mathrm{M}+2 \mathrm{H}]^{2+}(\mathbf{b})$ and $[\mathrm{M}+\mathrm{H}]^{+}$ (c) ions of PRCGVPDVA, PRC $\left(\mathrm{SO}_{2} \mathrm{H}\right)$ GVPDVA, and $\mathrm{PRC}\left(\mathrm{SO}_{3} \mathrm{H}\right)$ GVPDVA.

role in the fragmentation of the $[\mathrm{M}+\mathrm{H}]^{+}$ion of $\mathrm{PRC}\left(\mathrm{SO}_{3} \mathrm{H}\right) \mathrm{GVPDVA}$ than intramolecular ionic interaction between the side chains of acidic and basic amino acid residues.

\section{RGDGGGCR, RGDGGGC $\left(\mathrm{SO}_{2} \mathrm{H}\right) \mathrm{R}$, and $\mathrm{RGDGGGC}\left(\mathrm{SO}_{3} \mathrm{H}\right) \mathrm{R}$}

We also acquired the product-ion spectra of the $[\mathrm{M}+$ $2 \mathrm{H}]^{2+}$ and $\left[\mathrm{M}+\mathrm{H}^{+}\right.$ions of RGDGGGCR, RGDGGGC $\left(\mathrm{SO}_{2} \mathrm{H}\right) \mathrm{R}$, and RGDGGGC $\left(\mathrm{SO}_{3} \mathrm{H}\right) \mathrm{R}$, and the results are similar to the other three sets of peptides 


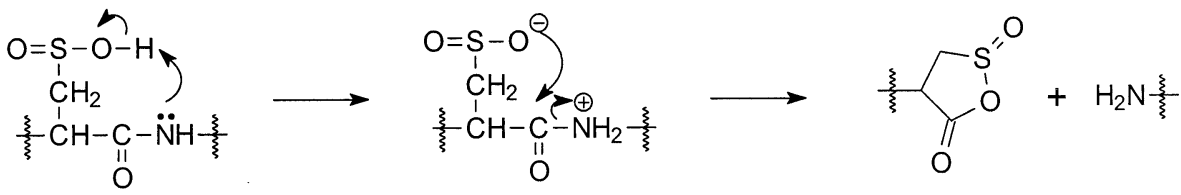

discussed above. In the product-ion spectrum of the [M $+2 \mathrm{H}]^{2+}$ ion of the unmodified peptide, we observed facile cleavage at the C-terminal side of aspartic acid with the formation of abundant $b_{3}$ and $y_{5}$ ions, though cleavages at other sites were also observed (Figure 5a). The oxidation of cysteine to Cys- $\mathrm{SO}_{2} \mathrm{H}$ results in marked change of the product-ion spectrum; cleavage occurs readily at the $\mathrm{C}$-terminal side of the modified cysteine and it gives abundant $b_{7}$ and $y_{1}$ ions (Figure 5b). Cleavage at the $\mathrm{C}$-terminal side of aspartic acid can also occur, but the abundances of the resulting $b_{3}$ and $y_{5}$ ions are much lower than those for the $b_{7}$ and $y_{1}$ ions (Figure 5b). In contrast, the replacement of cysteine with $\mathrm{Cys}-\mathrm{SO}_{3} \mathrm{H}$ does not give rise to enhanced cleavage at the $\mathrm{C}$-terminal side of $\mathrm{Cys}-\mathrm{SO}_{3} \mathrm{H}$ (Figure $5 \mathrm{c}$ ). The product-ion spectra of the $[\mathrm{M}+\mathrm{H}]^{+}$ions gave similar results (data not shown).

\section{"Break-down" Curves for the Fragmentations}

The facile cleavage at the C-terminal side of the Cys$\mathrm{SO}_{2} \mathrm{H}$ may imply that the collisional energy required for the fragmentation of $\mathrm{Cys}-\mathrm{SO}_{2} \mathrm{H}$-bearing peptides is lower than that of the unmodified peptides. To test this we acquired the product-ion spectra at different collisional energies and plotted the fraction of the parent ion intensity in total ion intensity versus the collisional energies ("break-down" curve).

The "break-down" curves (Figure 6) show that the oxidation of the Cys residue to Cys- $\mathrm{SO}_{2} \mathrm{H}$ or $\mathrm{Cys}-\mathrm{SO}_{3} \mathrm{H}$ makes the peptides more susceptible to fragmentation. The relative ease for the fragmentation of peptides containing $\mathrm{Cys}-\mathrm{SO}_{2} \mathrm{H}$ and $\mathrm{Cys}-\mathrm{SO}_{3} \mathrm{H}$ depends on both the sequence of the peptide and the number of protons present in the peptide ion. In this respect, the fragmentation of the $[\mathrm{M}+\mathrm{H}]^{+}$ion of $\operatorname{PFC}\left(\mathrm{SO}_{2} \mathrm{H}\right) \mathrm{G}$ requires lower collisional energy than that of $\mathrm{PFC}\left(\mathrm{SO}_{3} \mathrm{H}\right) \mathrm{G}($ Figure $6 \mathrm{a})$. Whereas the fragmentation of the $[\mathrm{M}+2 \mathrm{H}]^{2+}$ ions of PRC $\left(\mathrm{SO}_{2} \mathrm{H}\right)$ GVPDVA and PRC $\left(\mathrm{SO}_{3} \mathrm{H}\right)$ GVPDVA requires similar collisional energy, the fragmentation of the $[\mathrm{M}+\mathrm{H}]^{+}$ion of PRC $\left(\mathrm{SO}_{2} \mathrm{H}\right)$ GVPDVA needs lower collisional energy for fragmentation than that of PRC $\left(\mathrm{SO}_{3} \mathrm{H}\right)$ GVPDVA (Figure $6 \mathrm{~b}$ and $\mathrm{c}$ ).

\section{Conclusions}

In the presence of Fenton reagents, the cysteine residue in a peptide can be oxidized to $\mathrm{Cys}-\mathrm{SO}_{2} \mathrm{H}$ and $\mathrm{Cys}-$ $\mathrm{SO}_{3} \mathrm{H}$. Collisional activation of the protonated ions of those peptides leads to facile cleavage(s) at the Cterminal side of the Cys- $\mathrm{SO}_{2} \mathrm{H}$ to give the corresponding $b$ and/or $y$ ions. In addition, this cleavage is more facile for peptides containing a Cys- $\mathrm{SO}_{2} \mathrm{H}$ than for those bearing a Cys- $\mathrm{SO}_{3} \mathrm{H}$.

This observation appears to be general. In addition to the peptides studied in this paper, facile cleavage was observed at the C-terminal side of $\mathrm{Cys}-\mathrm{SO}_{2} \mathrm{H}$ in a peptide $\mathrm{C}\left(\mathrm{SO}_{2} \mathrm{H}\right) \mathrm{GVPDVAE}$ [8]. Similarly, the $\mathrm{y}_{6}$ ion is one of the most abundant ions observed in the production spectrum of the $[\mathrm{M}+3 \mathrm{H}]^{3+}$ ion of a peptide ESGSLSPEHGPVVVHC $\left(\mathrm{SO}_{2} \mathrm{H}\right) \mathrm{SAGIGR}$, and the formation of the $\mathrm{y}_{6}$ ion requires cleavage at the C-terminal side of the $\mathrm{Cys}_{-} \mathrm{SO}_{2} \mathrm{H}$ [26]. However, the $\mathrm{y}_{6}$ ion is much less abundant in the product-ion spectrum of the $[\mathrm{M}+$ $3 \mathrm{H}]^{3+}$ ion of the same peptide with the cysteine being oxidized to $\mathrm{Cys}-\mathrm{SO}_{3} \mathrm{H}$ [26]. Moreover, we demonstrated that the protonated ions of peptides containing a Cys$\mathrm{SO}_{2} \mathrm{H}$ require lower energy for the fragmentation than those bearing an unmodified cysteine.

Similar to the mechanism proposed for the cleavage of the amide bond at the C-terminal side of an aspartic acid [17], we proposed a mechanism for the cleavage at the amide bond that is C-terminal to the $\mathrm{Cys}-\mathrm{SO}_{2} \mathrm{H}$ (Scheme 1). The preferential cleavage of the amide bond at the C-terminal side of the $\mathrm{Cys}-\mathrm{SO}_{2} \mathrm{H}$ provides information for determining the site of cysteine oxidation. This, in combination with the facile formation of Cys$\mathrm{SO}_{2} \mathrm{H}$ from Cys, also affords a convenient way for the identification and localization of cysteine residue in a peptide.

\section{References}

1. Hamann, M.; Zhang, T.; Hendrich, S.; Thomas, J. A. Quantitation of Protein Sulfinic and Sulfonic Acid, Irreversibly Oxidized Protein Cysteine Sites in Cellular Proteins. Methods Enzymol. 2002, 348, 146-156.

2. Claiborne, A.; Yeh, J. I.; Mallett, T. C.; Luba, J.; Crane, E. J. III.; Charrier, V.; Parsonage, D. Protein-Sulfenic Acids: Diverse Roles for an Unlikely Player in Enzyme Catalysis and Redox Regulation. Biochemistry 1999, 38, 15407-15416.

3. Claiborne, A.; Mallett, T. C.; Yeh, J. I.; Luba, J.; Parsonage, D. Structural, Redox, and Mechanistic Parameters for CysteineSulfenic Acid Function in Catalysis and Regulation. Adv. Protein Chem. 2001, 58, 215-276.

4. Kim, J. R.; Yoon, H. W.; Kwon, K. S.; Lee, S. R.; Rhee, S. G. Identification of Proteins Containing Cysteine Residues that are Sensitive to Oxidation by Hydrogen Peroxide at Neutral pH. Anal. Biochem. 2000, 283, 214-221.

5. Yang, K. S.; Kang, S. W.; Woo, H. A.; Hwang, S. C.; Chae, H. Z.; Kim, K.; Rhee, S. G. Inactivation of Human Peroxiredoxin I During Catalysis as the Result of the Oxidation of the Catalytic Site Cysteine to Cysteine-Sulfinic Acid. J. Biol. Chem. 2002, 277, 38029-38036.

6. Woo, H. A.; Chae, H. Z.; Hwang, S. C.; Yang, K. S.; Kang, S. W.; Kim, K.; Rhee, S. G. Reversing the Inactivation of 
Peroxiredoxins Caused by Cysteine Sulfinic Acid Formation. Science 2003, 300, 653-656.

7. Winterbourn, C. C.; Metodiewa, D. Reactivity of Biologically Important Thiol Compounds with Superoxide and Hydrogen Peroxide. Free Rad. Biol. Med. 1999, 27, 322-328.

8. Fu, X.; Kassim, S. Y.; Parks, W. C.; Heinecke, J. W. Hypochlorous Acid Oxygenates the Cysteine Switch Domain of ProMatrilysin (MMP-7). A Mechanism for Matrix Metalloproteinase Activation and Atherosclerotic Plaque Rupture by Myeloperoxidase. J. Biol. Chem. 2001, 276, 41279-41287.

9. Murakami, T.; Nojiri, M.; Nakayama, H.; Odaka, M.; Yohda, M.; Dohmae, N.; Takio, K.; Nagamune, T.; Endo, I. PostTranslational Modification is Essential for Catalytic Activity of Nitrile Hydratase. Protein Sci. 2000, 9, 1024-1030.

10. Biteau, B.; Labarre, J.; Toledano, M. B. ATP-Dependent Reduction of Cysteine-Sulphinic Acid by S. cerevisiae sulphiredoxin. Nature 2003, 425, 980-984.

11. Pullar, J. M.; Vissers, M. C.; Winterbourn, C. C. Glutathione Oxidation by Hypochlorous Acid in Endothelial Cells Produces Glutathione Sulfonamide as a Major Product but not Glutathione Disulfide. J. Biol. Chem. 2001, 276, 22120-22125.

12. Fu, X.; Mueller, D. M.; Heinecke, J. W. Generation of Intramolecular and Intermolecular Sulfenamides, Sulfinamides, and Sulfonamides by Hypochlorous Acid: A Potential Pathway for Oxidative Cross-Linking of Low-Density Lipoprotein by Myeloperoxidase. Biochemistry 2002, 41, 1293-1301.

13. Hunt, D. F.; Yates, J. R. III.; Shabanowitz, J.; Winston, S.; Hauer, C. R. Protein Sequencing by Tandem Mass Spectrometry. Proc. Natl. Acad. Sci. U.S.A. 1986, 83, 6233-6237.

14. Biemann, K. Sequencing of Peptides by Tandem Mass Spectrometry and High-Energy Collision-Induced Dissociation. Methods Enzymol. 1990, 193, 455-479.

15. Papayannopoulos, I. A. The Interpretation of Collision-Induced Dissociation Tandem Mass Spectra of Peptides. Mass Spectrom. Rev. 1995, 14, 49-73.

16. Burlet, O.; Yang, C. Y.; Gaskell, S. J. Influence of Cysteine to Cysteic Acid Oxidation on the Collision-Activated Decomposition of Protonated Peptides: Evidence for Intraionic Interactions. J. Am. Soc. Mass Spectrom. 1992, 3, 337-344.
17. Yu, W.; Vath, J. E.; Huberty, M. C.; Martin, S. A. Identification of the Facile Gas-Phase Cleavage of the Asp-Pro and Asp-Xxx Peptide Bonds in Matrix-Assisted Laser Desorption Time-ofFlight Mass Spectrometry. Anal. Chem. 1993, 65, 3015-3023.

18. Burlet, O.; Yang, C.-Y.; Guyton, J. R.; Gaskell, S. J. Tandem Mass Spectrometric Characterization of a Specific Cysteic Acid Residue in Oxidized Human Apoprotein B-100. J. Am. Soc. Mass Spectrom. 1995, 6, 242-247.

19. Qin, J.; Chait, B. T. Preferential Fragmentation of Protonated Gas-Phase Peptide Ions Adjacent to Acidic Amino Acid Residues. J. Am. Chem. Soc. 1995, 117, 5411-5412.

20. Summerfield, S. G.; Cox, K. A.; Gaskell, S. J. The Promotion of d-Type Ions During the Low Energy Collision-Induced Dissociation of Some Cysteic Acid-Containing Peptides. J. Am. Soc. Mass Spectrom. 1997, 8, 25-31.

21. Tsaprailis, G.; Nair, H.; Somogyi, A.; Wysocki, V. H.; Zhong, W.; Futrell, J. H.; Summerfield, S. G.; Gaskell, S. J. Influence of Secondary Structure on the Fragmentation of Protonated Peptides. J. Am. Chem. Soc. 1999, 121, 5142-5154.

22. Tsaprailis, G.; Somogyi, A.; Nikolaev, E. N.; Wysocki, V. H. Refining the Model for Selective Cleavage at Acidic Residues in Arginine-Containing Protonated Peptides. Int. J. Mass Spectrom. 2000, 195/196, 467-479.

23. Atherton, E.; Sheppard, R. C. In Solid Phase Peptide Synthesis: A Practical Approach; Rickwood, D.; Hames, B. D., Eds.; Oxford University Press: Oxford, UK, 1989, pp 1-92.

24. Breci, L. A.; Tabb, D. L.; Yates, J. R. III.; Wysocki, V. H. Cleavage N-Terminal to Proline: Analysis of a Database of Peptide Tandem Mass Spectra. Anal. Chem. 2003, 75, 19631971.

25. Tabb, D. L.; Smith, L. L.; Breci, L. A.; Wysocki, V. H.; Lin, D.; Yates, J. R. III. Statistical Characterization of Ion Trap Tandem Mass Spectra from Doubly Charged Tryptic Peptides. Anal. Chem. 2003, 75, 1155-1163.

26. DeGnore, J. P.; Konig, S.; Barrett, W. C.; Chock, P. B.; Fales, H. M. Identification of the Oxidation States of the Active Site Cysteine in a Recombinant Protein Tyrosine Phosphatase by Electrospray Mass Spectrometry Using On-Line Desalting. Rapid Commun. Mass Spectrom. 1998, 12, 1457-1462. 